\title{
STRUKTUR PASAR MINYAK KAYU PUTIH (MELALEUCA LEUCADENDRON OIL) (Studi Kasus di Kecamatan Namlea Kabupaten Buru-Maluku)
}

\author{
Silvana Maulidah \\ Jurusan Sosial Ekonomi Pertanian Universitas Brawijaya Malang \\ Email: silvana.maulidah@yahoo.com
}

\begin{abstract}
In Indonesia, Melaleuca leucadendron Oil is only produced in several regions, including the District of Buru, Ambon, Seram, New Guinea, Java, and Borneo. This condition is a good opportunity to develop Agro Oil White Wood, White Wood Oil Agro-industry presence in the operations must be taken to ensure that producers are able to survive in a market situation that took place, so hopefully will create an effective and efficient market. This study aims to analyze the structure of eucalyptus oil agro-industry market. Determiningthe location of the research done by purposive (deliberately) that is in the Regency of Buru as the largest producer of eucalyptus plants in the Moluccas. Data analysis methods used were qualitative (descriptive) and quantitative analysis. Descriptive analysis is used in the determination of market structure include the degree of product differentiation, barriers to market entry, and the level of market knowledge and determination of market behavior including pricing policies, institutional system of market and marketing functions. The quantitative analysis used to determine the degree of market concentration that is measured market share. The results of this study indicate that the market structure of Melaleuca leucadendron Oil agro-industry in the regency of Buru including in markets characterized by monopolistic competition there are many sellers in the market with the same basic product but have been differentiated. From the results of existing research suggested that Melaleuca leucadendron Oil industry need to consider the market structure in determining the price. Melaleuca leucadendron Oil agro need to increase production and marketing activities by creating the uniqueness of the diversification of products so that manufacturers can increase revenue and avoid market saturation.
\end{abstract}

Kaywords: Market structure, market concentration, diversification of products.

\section{PENDAHULUAN}

Tanaman kayu putih (Melaleuca cajuputi sub sp. cajuputi) di Indonesia tersebar secara alami, terutama di Pulau Jawa dan Maluku dengan memanfaatkan daunnya untuk disuling secara tradisional oleh masyarakat maupun secara komersial menjadi minyak atsiri yang bernilai ekonomi tinggi. Tanaman kayu putih sangat cocok di daerah kering karena dapat menghasilkan minyak dengan kualitas dan bobot yang lebih tinggi dibandingkan dengan daerah yang tanahnya agak basah. Namun pohon kayu putih memiliki daya adaptasi yang sangat baik, sehingga dapat tumbuh di daerah basah dan kawasan rawa sekalipun.

Hal yang memprihatinkan ialah, Indonesia termasuk salah satu pengimpor terbesar minyak kayu putih. Minyak kayu putih impor umumnya berasal dari China dan Vietnam. Berdasarkan data yang didapat Balitbanghut menunjukan bahwa kebutuhan domestik minyak kayu putih adalah 1.500 ton/tahun namun saat ini Indonesia hanya mampu memproduksi kurang dari 500 ton/tahun. Karena itu sisanya harus diimpor. Sebagai kajian yang dilakukan menunjukan bahwa produksi minyak kayu putih masih rendah dan jauh dibawah kebutuhan dalan negeri baik untuk kebutuhan rumah tangga maupun industri farmasi dan kosmetik.

Berdasarkan Badan Pusat Statistik indonesia tahun 2006, dijelaskan bahwa Pulau Buru menjadi penghasil tanaman kayu putih terbesar di kawasan Indonesia, kemudian Seram dan Ambon. Melihat potensi tanaman kayu putih di indonesia tersebut, maka pengolahan tanaman kayu putih memiliki prospek yang baik untuk dikembangkan.

Tabel 1. Data Produksi Minyak Kayu Putih Di Indonesia Tahun 2006

\begin{tabular}{lc}
\hline Daerah & Produksi Minyak Kayu Putih (ton) \\
\hline Buru & 182,36 \\
Ambon & 97,46 \\
Seram & 84,90 \\
Irian & 60,90 \\
Jawa & 42,45 \\
Kalimantan & 20,39 \\
\hline
\end{tabular}

Sumber: BPS (2006)

Agroindustri minyak kayu putih sebagai salah satu bentuk industri kecil rumah tangga yang mengolah daun kayu putih menjadi minyak kayu putih, memiliki peran dalam peningkatkan nilai tambah dan meningkatkan pendapatan serta menyerap tenaga kerja. Oleh karena itu sampai saat 
ini, agroindustri minyak kayu putih berkembang cukup pesat di beberapa daerah di Indonesia, salah satunya di Kabupaten Buru. Dengan peluang pasar yang makin baik dan meluas, tidak semua perusahaan minyak kayu puth mampu menghadapinya. Berdasarkan informasi Departemen Perindustrian dan Perdagangan Kabupaten Buru menyebutkan bahwa sebelum terjadinya krisis moneter tahun 1997, jumlah usaha agroindustri minyak kayu putih sangat banyak, kondisi ini memberikan dampak yang baik terhadap perekonomian Pulau Buru. Namun hal ini berubah semenjak terjadinya krisis moneter, yang mengakibatkan gejolak perekonomian sehingga banyak perusahaan agroindustri minyak kayu putih menutup dan beralih pada usaha lain. Bagi perusahaan yang masih bertahan dibutuhkan strategi untuk menghadapi persaingan pasar.

Dalam situasi yang tidak menentu dan tidak menguntungkan akibat krisis moneter, hal yang sangat perlu untuk dilakukan adalah menganalisis lingkungan dengan cermat. Dinamika lingkungan eksternal dan internal sebagaimana yang terjadi, akan memunculkan ancaman-ancaman baru dalam persaingan, disamping tidak menutup kemungkinan juga akan memunculkan berbagai peluang. Analisis struktur pasar akan menghasilkan informasi yang sangat penting sebagai dasar untuk merumuskan strategi yang terbaik, agar perusahaan dapat bertahan dalam persaingan pasar.

Dari data dan informasi mengenai kondisi pengusaha agroindustri minyak kayu putih di daerah penelitian, selain faktor-faktor budidaya dan modal, faktor lain yang mempengaruhi adalah keterbatasan akan berbagai faktor pendukung utama dalam pemasaran, seperti informasi tentang perubahan harga dan peluang pasar di daerah Maluku dan Pulau Jawa, serta dana untuk pembayaran distribusi, promosi, pengetahuan mengenai wawasan bisnis dan komunikasi. Hal ini menyebabkan pemasaran minyak kayu putih hanya mampu melayani pasar lokal.

Permasalahan lain dalam hal pemasaran yang sering menjadi faktor pembatas bagi perkembangan minyak kayu putih adalah banyaknya pihak perantara yang terlibat dalam mata rantai distribusinya, sedangkan posisi petani dalam pemasaran cenderung berada di pihak yang lemah (price taker) dengan bagian harga yang diterima terlalu rendah dibandingkan dengan bagian harga yang diterima pengecer. Hal ini dapat menimbulkan inefisiensi dalam sistem pemasaran tersebut. Untuk melihat sistem pemasaran maka digunakan analisis stuktur pasar. Berdasarkan apa yang telah diuraikan diatas, maka secara lebih eksplisit rumusan masalah yang dapat diajukan adalah: "Bagaimanakah struktur pasar minyak kayu putih di Kabupaten Buru, Maluku?”

\section{Tujuan Penelitian}

Menganalisis struktur pasar minyak kayu putih di Kecamatan Namlea-Kabupaten Buru, Maluku.

\section{Kegunaan Penelitian}

1. Memberikan informasi atau masukan bagi pihakpihak yang berkepentingan dengan permasalahan ini, khususnya produk minyak kayu putih.

2. Sebagai informasi bagi pemerintah dalam menetapkan kebijakan yang berkaitan dengan produk minyak kayu putih

3. Sebagai bahan acuan bagi peneliti lain yang ingin meneliti lebih lanjut mengenai produk minyak kayu putih.

\section{METODE PENELITIAN}

\section{Metode Penentuan Lokasi}

Penelitian dilakukan di Namlea-Kabupaten Buru, Maluku. Lokasi penelitian ditentukan secara sengaja (Purposive), dikarenakan Pulau Buru merupakan sentra usaha tani tanaman kayu putih dan agroindustri minyak kayu putih.

\section{Metode Penentuan Responden}

Responden dalam penelitian ini ada 2 (dua), yaitu: produsen (agroindustri) minyak kayu putih dan lembaga pemasaran minyak kayu putih. Metode penentuan responden produsen (agroindustri) minyak kayu putih menggunakan metode sensus yaitu dengan mengambil semua produsen (agroindustri) yang ada di Namlea Kabupaten Buru yang berjumlah 40 produsen (agroindustri). Sedangkan untuk pengambilan responden yang berasal dari lembaga pemasaran digunakan metode Snow ball sampling.

\section{Metode Analisis Data}

Penelitian ini difokuskan untuk melihat struktur pasar minyak kayu putih di Kabupaten Buru, Maluku. Struktur pasar yang terjadi dapat dianalisis berdasarkan unsur-unsur berikut ini, antara lain: Derajat Konsentrasi Pasar (dengan beberapa pendekatan kuantitatif, antara lain: Analisis Pangsa Pasar/Market Share, Indeks Herfindahl, CR4/Concentration Ratio For Four The Biggest Firm, dan Indeks Rosenbluth), serta Derajat diferensiasi produk, Hambatan Masuk Pasar dan Tingkat Pengetahuan Pasar. 


\section{Derajat Konsentrasi Pasar}

\section{A. Pangsa Pasar (Market Share)}

Pangsa pasar (market share) adalah prosentase dari total penjualan pada suatu target pasar yang diperoleh dari suatu perusahaan (potensi pasar dibagi jumlah penjualan).

B. Indeks Herfindahl

Alat analisis ini bertujuan untuk mengetahui derajat konsentrasi pembeli dari suatu wilayah pasar, sehingga bisa diketahui secara umum gambaran imbangan kekuatan posisi tawar menawar produsen terhadap pembeli.

C. CR4 (Concentration Ratio For Four The Biggest Firm)

Analisis ini bertujuan untuk mengetahui derajat konsentrasi 4 pembeli terbesar dari suatu wilayah pasar sehingga dapat diketahui secara umum gambaran imbangan kekuatan posisi tawarmenawar produsen terhadap pembeli.

D. Indeks Rosenbluth (R)

Indeks Rosenbluth adalah alat analisis untuk mengetahui tingkat konsentrasi lembaga pemasaran yang terlibat dalam pemasaran suatu komoditi pada suatu wilayah pasar.

\section{$\underline{\text { Derajat Diferensiasi Produk }}$}

Diferensiasi produk dapat menjadi halangan bagi produsen (agroindustri) lain untuk memasuki pasar. Persaingan akan berjalan dengan sempurna apabila pembeli dapat membandingkan barang yang satu dengan barang yang lain. Analisis derajat diferensiasi produk lebih lanjut akan dibahas dengan menggunakan analisis deskriptif (kualitatif).

\section{Hambatan Masuk Pasar}

Segala sesuatu yang merintangi pesaing-pesaing baru untuk masuk ke pasar akan memperbesar kekuatan produsen (agroindustri) yang telah ada. Jika rintangan tersebut tidak ada, maka pesaing baru akan bebas masuk pasar, sehingga monopsoni murni hanya memiliki kekuatan pasar yang kecil. Dalam penelitian ini hambatan masuk pasar akan dibahas secara deskriptif (kualitatif).

\section{Tingkat Pengetahuan Pasar}

Sistem pemasaran yang efisien mengharuskan para pelaku pasar mempunyai kemampuan untuk menguasai informasi pasar. Dalam penelitian ini Tingkat Pengetahuan Pasar akan dibahas secara deskriptif (kualitatif).

\section{HASIL PENELITIAN}

Struktur pasar pada hakekatnya ditentukan oleh jumlah dan ukuran perusahaan dalam pasar, diferensiasi produk, hambatan masuk pasar dan pengetahuan tentang informasi pasar. Kekuatan membeli dan menjual dapat diketahui melalui jumlah perusahaan yang ada dalam suatu pasar. Suatu perusahan dapat memiliki kekuatan pasar apabila perusahaan tersebut bisa mempengaruhi harga yang diterimanya (price maker).

Dari hasil penelitian diperoleh bahwa, terdapat 1 (satu) saluran pemasaran produk minyak kayu putih di Kabupaten Buru, Maluku, yaitu: Produsen (agroindustri) - Agen - Pengecer. Dimana jumlah masing-masing adalah 40 produsen (agroindustri), 24 Pedagang Agen, dan 82 Pedagang Pengecer.

Hasil yang diperoleh dari penelitian struktur pasar minyak kayu putih, berdasarkan beberapa pendekatan kuantitatif dan kualitatif (deskriptif) adalah:

\section{Derajat Konsentrasi Pasar}

Untuk mengetahui derajat konsentrasi pasar minyak kayu putih, dilakukan pendekatan secara kuantitatif, antara lain: Pangsa Pasar (Market Share); Indeks Herfindahl; CR4 (Concentration Ratio For Four The Biggest Firm); dan Indeks Rosenbluth pada masing-masing lembaga pemasaran yang ada. Hasil perhitungannya adalah sebagai berikut:

\section{A. Pangsa Pasar (Market Share)}

\section{Tabel 2. Rekapitulasi Pangsa Pasar (Market Share) pada Lembaga Pemasaran Minyak Kayu Putih}

\begin{tabular}{clcc}
\hline No. & $\begin{array}{c}\text { Lembaga } \\
\text { Pemasaran }\end{array}$ & $\begin{array}{c}\text { Market Share } \\
\mathbf{( \% )}\end{array}$ & Struktur Pasar \\
\hline 1 & Agen & 9,77 & Persaingan Sempurna \\
2 & Pengecer & 6,19 & Persaingan Sempurna \\
\hline
\end{tabular}

Dari Tabel 2 dapat dilihat bahwa tidak ada satu pun lembaga pemasaran yang memiliki pangsa pasar (market share) yang berarti dari market share total. Ini menunjukkan bahwa struktur pasar minyak kayu putih yang terjadi adalah pasar persaingan sempurna. 
B. Indeks Herfindahl

Tabel 3. Rekapitulasi Indeks Herfindahl pada Lembaga Pemasaran Minyak Kayu Putih

\begin{tabular}{cccc}
\hline No. & $\begin{array}{c}\text { Lembaga } \\
\text { Pemasaran }\end{array}$ & $\begin{array}{c}\text { Indeks } \\
\text { Herfindahl }\end{array}$ & Struktur Pasar \\
\hline 1 & Agen & 0,046 & Persaingan Sempurna \\
2 & Pengecer & 0,031 & Persaingan Sempurna \\
\hline
\end{tabular}

Dari Tabel 3 dapat dilihat bahwa nilai Indeks Herfindahl pada kedua lembaga pemasaran minyak kayu putih mendekati 0 . Sehingga bisa disimpulkan bahwa struktur pasar minyak kayu puth yang terjadi adalah pasar persaingan sempurna.

\section{CR4 (Concentration Ratio For Four The Biggest Firm)}

Tabel 4. Rekapitulasi CR4 pada Lembaga Pemasaran Minyak Kayu Putih

\begin{tabular}{clcc}
\hline No. & $\begin{array}{c}\text { Lembaga } \\
\text { Pemasaran }\end{array}$ & CR4 & Struktur Pasar \\
\hline 1 & Agen & 0,25 & Persaingan Sempurna \\
2 & Pengecer & 0,29 & Persaingan Sempurna \\
\hline
\end{tabular}

Dari Tabel 4 dapat dilihat bahwa nilai CR4 pada kedua lembaga pemasaran minyak kayu putih $<40 \%$, yaitu $25 \%(0,25)$ dan $29 \%(0,29)$. Angka ini menunjukkan bahwa struktur pasar minyak kayu putih yang terjadi adalah pasar persaingan sempurna, hal ini diperkuat dengan kondisi di lapang bahwa tidak ada kegiatan yang berarti dalam rangka diferensiasi produk.

D. Indeks Rosenbluth (R)

Tabel 5. Rekapitulasi Indeks Rosenbluth pada Lembaga Pemasaran Minyak Kayu Putih

\begin{tabular}{cccc}
\hline No. & $\begin{array}{c}\text { Lembaga } \\
\text { Pemasaran }\end{array}$ & $\begin{array}{c}\text { Indeks } \\
\text { Rosenbluth }\end{array}$ & Struktur Pasar \\
\hline 1 & Agen & 0,005 & Persaingan Sempurna \\
2 & Pengecer & 0,040 & Persaingan Sempurna \\
\hline
\end{tabular}

Dari Tabel 5 dapat dilihat bahwa nilai Indeks Rosenbluth pada kedua lembaga pemasaran minyak kayu putih cenderung mendekati batas minimum. Sehingga dapat dikatakan bahwa struktur pasar minyak kayu putih yang terjadi adalah mengarah pada pasar persaingan sempurna. Kesimpulan yang diperoleh dari semua perhitungan pada pendekatan derajat konsentrasi pasar adalah, struktur pasar produk minyak kayu putih cenderung mengarah pada pasar persaingan sempurna.

\section{Derajat Diferensiasi Produk}

Ada beberapa aspek pengukuran diferensiasi produk minyak kayu putih yang digunakan, diantaranya:

A. Kualitas: Kualitas produk minyak kayu putih yang tinggi bermula dari bahan baku, hingga tatacara penyulingan produk.

B Kemasan: Produk minyak kayu putih yang dihasilkan dikemas dalam bentuk botol. Kemasan itu sendiri dimaksudkan untuk melindungi dan mengidentifikasi produk. Di tempat penelitian semua produk minyak kayu putih tidak dilakukan pengemasan secara khusus, hanya diwadahi dalam botol.

C Aroma: Dalam hal aroma, produk minyak kayu putih mempunyai suatu ciri khas yang bisa dibedakan oleh konsumen apa produk minyak kayu putih ini asli atau campuran.

\section{Hambatan Masuk Pasar}

Usaha agroindustri minyak kayu putih merupakan usaha yang berjalan secara turun-temurun. Sebagian besar para produsen minyak kayu putih hanya meneruskan apa yang telah dirintis oleh pendahulunya dan berusaha untuk mengembangkan dan memelihara. Namun, ada pula para produsen yang memiliki industri minyak kayu putih bukan berasal dari para pendahulu. Melainkan mereka membuka industri secara mandiri berdasar dari pengetahuan dan keterampilan yang dimiliki dimana sebelumnya mereka pernah bekerja pada agroindustri minyak kayu putih yang sudah berdiri lama. Produsen inilah merupakan pendatang baru yang mencoba untuk masuk dalam pasar minyak kayu putih. Pada pasar minyak kayu putih, tidak ada hambatan yang cukup berarti untuk masuk dan keluar dari usaha agroindustri minyak kayu putih. Hal ini ditunjukkan dengan tidak adanya peraturan yang bersifat legal yang mengikat suatu industri untuk menjalankan usahanya.

\section{Tingkat Pengetahuan Pasar}

Dalam agroindustri minyak kayu putih, terdapat kemudahan dalam memperoleh informasi pasar serta tidak ada ketergantungan antar pelaku pemasaran. Persaingan berasal dari semua agroindustri minyak kayu putih di dalam pasar dimana harga relatif sama, yang berarti konsumen bisa mengembangkan pilihan atas produk yang ditawarkan oleh penjual. Di sisi lain, biaya produksi relatif stabil dan sama sehingga keuntungan yang diperoleh pun relatif sama. 
Persaingan yang terjadi pada pasar industri minyak kayu putih di Kabupaten Buru sangat kompetitif. Akan tetapi persaingan tersebut tidak sampai menekan harga. Strategi yang dijalankan adalah meningkatkan pelayanan kepada konsumen melalui pengiriman barang ke tempat tujuan sesuai permintaan konsumen serta melakukan pengemasan dalam wadah dengan ukuran/takaran sesuai permintaan konsumen.

\section{KESIMPULAN DAN SARAN}

\section{Kesimpulan}

Kesimpulan yang dapat diambil adalah Struktur pasar pada produk minyak kayu putih bersifat/ mengarah pada pasar persaingan sempurna. Hal tersebut didasarkan pada hasil analisis sebagai berikut:

1. Derajat Konsentrasi Pasar; dengan beberapa pendekatan kuantitatif, antara lain: Analisis Pangsa Pasar/Market Share, Indeks Herfindahl, CR4/ Concentration Ratio For Four The Biggest Firm, dan Indeks Rosenbluth; semua menghasilkan nilai yang menunjukkan bahwa pasar mengarah pada persaingan sempurna.

2. Tidak terdapat kegiatan yang berarti dalam rangka diferensiasi pada produk minyak kayu putih

3. Tidak ada hambatan untuk masuk dan keluar pasar produk minyak kayu putih.

4. Adanya kemudahan dalam memperoleh informasi pasar serta tidak ada ketergantungan antar pelaku pemasaran, ini dikarenakan diantara pelaku pemasaran mempunyai tingkat pengetahuan pasar yang sama.

\section{Saran}

1. Produsen agroindustri minyak kayu puth disarankan melakukan perbaikan kualitas produk minyak kayu putih, dengan cara pemilihan bahan baku serta tata cara penyulingan yang baik. Kegiatan dalam rangka diferensiasi produk juga diperlukan, misalkan dalam hal keunikan produk dengan pengemasan botol dan kardus yang lebih menarik sehingga lebih diminati oleh konsumen

2. Para pedagang (lembaga pemasaran) minyak kayu putih disarankan ikut melakukan kegiatan promosi yang intensif.
3. Bagi pemerintah hendaknya memberikan pembinaan dan perlindungan pada produsen agroindustri minyak kayu putih sehingga produk minyak kayu putih mampu bersaing di pasar.

4. Bagi peneliti selanjutnya disarankan mengkaji lebih dalam mengenai potensi dan strategi pasar produk minyak kayu putih di Kabupaten Buru.

\section{DAFTAR PUSTAKA}

Abidin, E.Z. dan A Kaumesakh. 1993. Beberapa Catatan Tentang Minyak Kayu Putih di Indonesia. Direktorat Jendral Kehutanan. Direktorat Pemasaran. Jakarta

Abimanju, 2006. Taktik Diferensiasi. Departemen Keuangan Republik Indonesia. (Available online with updates at http:// Webmaster @. go. id)

Karta Saputra. 1992. Marketing Produk Pertanian dan Industri. PT Rineka Cipta. Jakarta

Kirana, Wihana. 1993. Pengantar Ekonomi Industri (Pendekatan Struktur, Perilaku dan Kinerja Pasar). BPFE. Yogyakarta.

Mallen, B, 1964. Introducing The Marketing Channel to Price Theory, Journal of Marketing, (28)3:29-33.

Analisis Struktur, Perilaku dan Penampilan Pasar (SCP) Pada Pemasaran Tembakau Vooroogst (Studi kasus di Desa Lengkong, Kec. Mumbulsari, Kab. Jember). Thesis Program Pascasarjana Universitas Brawijaya Malang.

Sastrowardoyo. 1993. Prioritas Penanaman Modal Agroindustri dalam Permodalan Agroindustri. PPA CIDES UQ. Jakarta

Schree, F.M. and Ross, David. 1990. Industrial Market Structure and Economic Performance (Third Edition). Houghton Miffin Company. USA.

Sheperd, William G. 1997. The Economics of Industrial Organization (Fourth Edition). PrenticeHall. USA.

Soepardi, R. 1953. Perusahaan Minyak Kayu Putih Rimba Indonesia Vol. II. Jakarta.

Sumadiwangsa, S. 1976. Teknik Pengolahan dan Kualitas Minyak Kayu Putih. Lembaga Penelitian Hasil Hutan. Bogor. 